\title{
Lomitapide affects HDL composition and function
}

R. Yahya ${ }^{1 *}$, E. Favari ${ }^{2 *}$, L. Calabresi ${ }^{3}$, A.J.M. Verhoeven ${ }^{1}$, F. Zimetti ${ }^{2}$, M.P. Adorni ${ }^{2}$, M. Gomaraschi ${ }^{3}$, M. Averna ${ }^{4}$, A.B. Cefalù ${ }^{4}$, F. Bernini ${ }^{2}$, E.J.G. Sijbrands ${ }^{1}$, M.T. Mulder ${ }^{1}$, J.E. Roeters van Lennep ${ }^{1}$

${ }^{1}$ Department of Internal Medicine, division Pharmacology, Vascular and Metabolic Diseases, Erasmus University Medical Center, Rotterdam, the Netherlands; ' 2 Department of Pharmacy, University of Parma, Parma, Italy;

${ }^{3}$ Centro Grosi Paoletti, Dipartimento di Scienze Farmacologiche e Biomolecolari, Università degli Studi di Milano, Milan, Italy; ${ }^{4}$ Department of Internal Medicine and Medical Specialties DIBIMIS, School of Medicine, University of Palermo, Palermo, Italy.

\section{Corresponding author:}

Dr. J.E. Roeters van Lennep

Department of Internal Medicine, Erasmus Medical Center

Adress: Box 2040, 3000 CA Rotterdam, The Netherlands

Fax:+31 107033639 Tel.: +31 3110703519

E-mail j.roetersvanlennep@erasmusmc.nl

Word count (main text): $1392(\max 1500)$

Abstract word count: 150 (max 150)

References: $22(\max 25)$

Number of figures and tables: $2(\max 2)$

*Two authors contributed equally to the manuscript 


\section{Abstract (150 words, max 150)}

Background: Lomitapide reduces low-density lipoprotein-cholesterol (LDL-C) but also highdensity lipoprotein-cholesterol (HDL-C) levels. The latter may reduce the clinical efficacy of lomitapide. We investigated the effect of lomitapide on HDL-C levels and on cholesterol efflux capacity (CEC) of HDL in patients with homozygous familial hypercholesterolemia (HoFH).

Methods and results: Four HoFH patients were treated with increasing dosages of lomitapide. Lomitapide decreased LDL-C (range -34 to $-89 \%$ ). Total HDL-C levels decreased (range -16 to $34 \%$ ) with a shift to buoyant HDL. ABCA1-mediated CEC decreased in all patients (range -39 to $-99 \%)$. The changes of total, ABCG1- and SR-BI-mediated CEC were less consistent.

Conclusion: Lomitapide decreased LDL-C and HDL-C levels. Our report raises the hypothesis that the anti-atherogenic potential of HDL seems to be unaffected as total CEC did not seem to change consistently. Combined with the reduction of atherogenic lipoproteins, the net effect of lomitapide appears to be beneficial in HoFH patients.

Key words: lomitapide, homozygous familial hypercholesterolemia, HDL, cholesterol efflux capacity, cholesterol lowering drugs 


\section{Introduction}

Homozygous familial hypercholesterolemia $(\mathrm{HoFH})$ is a rare disease caused by mutations in the $L D L R$ gene ${ }^{1,2}$. Untreated patients with $\mathrm{HoFH}$ are characterized by extremely raised low density lipoprotein-cholesterol levels (LDL-C) often exceeding $13 \mathrm{mmol} / \mathrm{L}$, rendering them susceptible to unparalleled premature atherosclerotic cardiovascular disease (CVD) and extensive aortic valve calcification and stenosis ${ }^{3,4}$. Without treatment the majority of patients with HoFH do not survive beyond their twenties. Early diagnosis and treatment of $\mathrm{HoFH}$ is therefore essential ${ }^{4}$.

A new treatment option for HoFH patients has become available with the microsomal triglyceride transfer protein (MTP) inhibitor, lomitapide, which resulted in $38 \%$ reduction of LDL-C levels in a phase III trial in $29 \mathrm{HoFH}$ patients ${ }^{5}$. However, high-density lipoprotein-cholesterol (HDL-C) levels were reduced by $12 \%{ }^{5-7}$. Although HDL-C levels show an inverse correlation with CVD risk, there is increasing evidence that HDL-mediated cholesterol efflux capacity (CEC) is a better predictor of CVD risk compared to HDL-C ${ }^{8,9}$. HDL removes cholesterol from the arterial wall by mediating cholesterol efflux via different pathways involving ABCA1, ABCG1, SR-BI, or aqueous diffusion of free cholesterol ${ }^{8}$.

In the present study, we determined the effect of lomitapide treatment on the capacity of HDL to promote cholesterol efflux from macrophages in four HoFH patients. 


\section{Methods}

\section{Study participants}

Four patients with $\mathrm{HoFH}$ receiving lomitapide as additional therapy in a clinical setting were included in the present study. They were amongst the first patients to be treated in a namedpatients-program worldwide. The diagnosis $\mathrm{HoFH}$ was based on genetic analysis and clinical phenotype (LDL-C>13mmol/L) ${ }^{4}$.

Three patients were recruited from the Erasmus Medical Center in the Netherlands and one from Palermo University Hospital in Italy, and were treated according to the prescribed protocol ${ }^{10}$. All patients provided written informed consent. This study was approved by the Medical Ethical Committees of the Erasmus Medical Center in the Netherlands and Palermo University in Italy.

\section{Blood analysis and measurements}

Venous blood was obtained after a 10-hour overnight fast, prior to treatment with lomitapide and every three or four weeks during the titration period. Plasma and serum obtained after centrifugation were stored at $-80^{\circ} \mathrm{C}$. All samples from different timepoints were analyzed in one run.

Lipoprotein profiles were generated with density-gradient ultracentrifugation using the method described by Proudfoot et.al ${ }^{11}$. Lipoproteins were separated according to their densities into $\mathrm{HDL}_{3}$ (1.125-1.21 g/ml), HDL $2(1.062-1 \cdot 125 \mathrm{~g} / \mathrm{ml}), \mathrm{LDL}(1 \cdot 019-1.063 \mathrm{~g} / \mathrm{ml})$, and IDL+VLDL $(<1 \cdot 019$ $\mathrm{g} / \mathrm{ml})^{12}$. Cholesterol and triglycerides were measured by an enzymatic method using Selectra $\mathrm{E}$ (DDS Diagnostic system, Istanbul, Turkey). Lipoprotein(a) [Lp(a)] plasma levels were measured using the Diasys immunoturbidimetric assay ${ }^{13}$.

ApoB and ApoA-I levels were measured by immunoturbidimetry on a c311 automatic analyzer (Roche Diagnostics). HDL subclasses were separated by non-denaturing two dimensional (2D) electrophoresis, as previously described ${ }^{14}$. The content of preß-HDL was calculated as percentage of total ApoA-I signal by densitometric analysis. 


\section{Cholesterol loading capacity}

Cholesterol loading capacity (CLC) was measured as previously described ${ }^{15}$ and defined as macrophage cholesterol content after exposure of cells to serum and expressed as $\mu \mathrm{g}$ cholesterol / $\mathrm{mg}$ protein.

Cholesterol efflux capacity.

Serum was depleted of apoB-containing lipoproteins in order to isolate the serum HDL fraction as previously described ${ }^{16}$. ApoB-depleted serum CEC was determined in human monocytes-derived macrophages THP-1 cultured in the presence of $100 \mathrm{ng} / \mathrm{ml}$ PMA for 72 hours to allow differentiation into macrophages. The apoB-depleted serum CEC specific for the three cholesterol efflux pathways (ABCA1, ABCG1, SR-BI) was evaluated in established cell culture models, as previously described ${ }^{17,18}$. Cellular cholesterol content before and after serum exposure was measured fluorimetrically as previously described ${ }^{15}$.

\section{Statistical analysis}

We performed descriptive analyses at baseline and during lomitapide treatment values and we present data as percentage change from baseline. The number of participants did not allow statistical inference. We used Microsoft Excel and Prism Graphpad 5 for the drawing of statistical graphs and data analysis. 


\section{Results}

\section{Baseline characteristics}

The baseline characteristics of the 4 patients are shown in Table 1. Patients 1, 3, and 4 had a history of CVD. All patients had some gastrointestinal-symptoms during lomitapide treatment but complaints were minimalized by a low-fat diet. Lomitapide treatment was interrupted in patient 1 because of non-adherence and in patient 4 because of persistent liver enzymes elevations $>5$ times upper limit of normal during treatment, which returned to normal after discontinuation of lomitapide.

\section{Atherogenic lipoproteins}

As expected the triglyceride levels (measured in intermediate density lipoprotein and very low density lipoprotein (IDL+VLDL)) decreased strongly in all 4 patients (range -78 to $-30 \%$ ). LDL-C and $a p o B$ levels decreased in a dose-dependent manner (range -34 to $-89 \%$ and -42 to $-89 \%$, respectively). Patient 2 and 3 achieved the LDL-C treatment target levels on maximum tolerated lomitapide dose. Patient 3 was treated with LDL-apheresis once every 1-2 weeks. This frequency was reduced to once every 8 to 10 weeks during lomitapide treatment. Lp(a) decreased in patient $1-3(-20 \%$ to $-74 \%)$, but remained unchanged in patient 4 .

The CLC of sera of the patients decreased by an average of $20 \%$ at maximum lomitapide dose in comparison to baseline (from $53.6 \pm 18.0$ to $42.8 \pm 12.3 \mathrm{ug}$ cholesterol/mg cell protein).

\section{HDL, ApoA-I and cholesterol efflux capacity}

Figure $1 \mathrm{~A}$ shows the individual cholesterol levels in total HDL-C and in HDL subclasses with increasing dosages of lomitapide of the 4 patients individually. The change in HDL-C levels (range -11 to $-34 \%$ ) was observed during treatment with lomitapide $5 \mathrm{mg} /$ day. In all patients, HDL-C levels remained stable with increasing lomitapide dosage. The reduction in HDL-C levels varied per $\mathrm{HDL}$ subclass, the $\mathrm{HDL}_{3} / \mathrm{HDL}_{2}$ ratio remained stable in patient 1 and decreased in the others 
(range -16 to $-68 \%$ ). Apo-Al levels and the content of Preß-HDL decreased with lomitapide treatment (range -9 to $-47 \%$ and -6 to $-40 \%$, respectively). This decrease was most pronounced with $5 \mathrm{mg} /$ day lomitapide treatment.

Figures 1B, 1C, 1D and 1E show the effect of lomitapide treatment on total CEC, and on cholesterol efflux via the different pathways for the four patients individually. Changes in total, SRBI-mediated and ABCG1-mediated cholesterol efflux were inconsistent. ABCA1-mediated cholesterol efflux decreased (-39 to $-99 \%)$ in all patients. 
Table 1. Baseline characteristics.

\begin{tabular}{|c|c|c|c|c|c|c|c|c|c|c|c|}
\hline $\begin{array}{l}\mathrm{Pa} \\
\text { tie } \\
\mathrm{nt}\end{array}$ & $\begin{array}{l}\mathrm{Ag} \\
\mathrm{e} \\
\text { (ye } \\
\text { ars } \\
\text { ) }\end{array}$ & $\begin{array}{l}\mathrm{S} \\
\mathrm{e} \\
\mathrm{x}\end{array}$ & $\begin{array}{l}\text { Ten } \\
\text { don } \\
\text { Xan } \\
\text { tho } \\
\text { mas }\end{array}$ & Mutations & $\begin{array}{c}\text { Total } \\
\text { cholesterol } \\
\text { levels } \\
\text { without } \\
\text { medication } \\
\text { (mmol/L) }\end{array}$ & $\begin{array}{c}\text { LDL } \\
\text { levels } \\
\text { without } \\
\text { lomitapi } \\
\text { de } \\
\text { (mmol/L } \\
\text { ) }\end{array}$ & $\begin{array}{l}\text { Age } \\
\text { of } \\
\text { ons } \\
\text { et } \\
\text { CVD } \\
\text { (yea } \\
\text { rs) }\end{array}$ & $\begin{array}{c}\text { Co- } \\
\text { medication } \\
\text { (mg/day) }\end{array}$ & $\begin{array}{l}\text { Maximu } \\
\text { m } \\
\text { lomitapi } \\
\text { de dose } \\
\text { (mg/day) }\end{array}$ & $\begin{array}{l}\text { Duration } \\
\text { lomitapide } \\
\text { treatment } \\
\text { (wks) }\end{array}$ & $\begin{array}{l}\text { Discountin } \\
\text { uation } \\
\text { lomitapide } \\
\text { treatment } \\
\text { (Yes/No) }\end{array}$ \\
\hline 1 & 29 & $F$ & + & $\begin{array}{l}\text {-G352D exon } 8 \\
\text {-2417insG } \\
\text { exon } 17\end{array}$ & 20,1 & 14,5 & 25 & $\begin{array}{c}\text { Atorvastatin } 80 \\
\text { Ezetimibe } 10\end{array}$ & 10 & 9.5 & Yes \\
\hline 2 & 20 & $\mathrm{~F}$ & + & $\begin{array}{l}-4.4 \mathrm{~kb}, \\
\text { duplication } \\
\text { exon } 12 \\
-2.5 \mathrm{~kb} \\
\text { deletion exon } \\
7,8\end{array}$ & 18,9 & 14,1 & - & $\begin{array}{c}\text { Atorvastatin } 80 \\
\text { Cholestagel } 2 x \\
1875\end{array}$ & 30 & 36.5 & No \\
\hline 3 & 36 & $M$ & + & $\begin{array}{l}\text {-G528D exon } \\
11 \\
-G 528 D \text { exon } \\
11\end{array}$ & 23,8 & $3,9^{*}$ & 26 & $\begin{array}{c}\text { Simvastatin } 60 \\
\text { Ezetimibe } 10\end{array}$ & 20 & 9 & No \\
\hline 4 & 62 & $F$ & + & $\begin{array}{l}16 \mathrm{~kb} \text { deletion } \\
\text { exon } 7-15\end{array}$ & 16,9 & 12,9 & 58 & $\begin{array}{l}\text { Questran 2x } \\
4 g r \\
\text { Modalim 2x } \\
100\end{array}$ & 10 & 9 & Yes \\
\hline
\end{tabular}

* LDL-apheresis once every 1-2 weeks 
Figure 1. HDL levels and total HDL-mediated CEC and CEC pathways at baseline and during lomitapide treatment per individual

A. HDL-C levels $\left(\mathrm{HDL}_{3}+\mathrm{HDL}_{2}\right)$ B. Total cholesterol efflux capacity $(\mathrm{CEC})$ of apoB-depleted serum with increasing lomitapide daily dose. C. HDL-mediated cholesterol efflux via ABCA1.

D. HDL-mediated cholesterol efflux via SR-BI. E. HDL-mediated cholesterol efflux via ABCG1.

A)

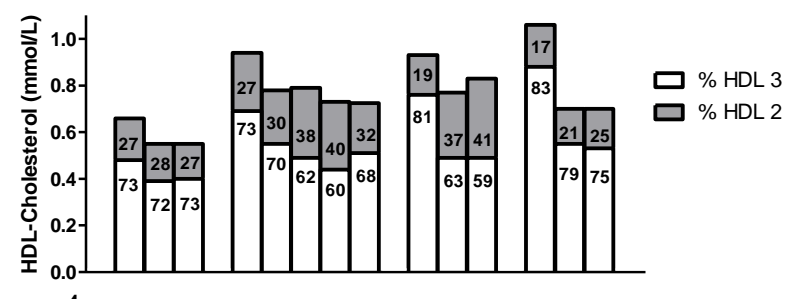

B)

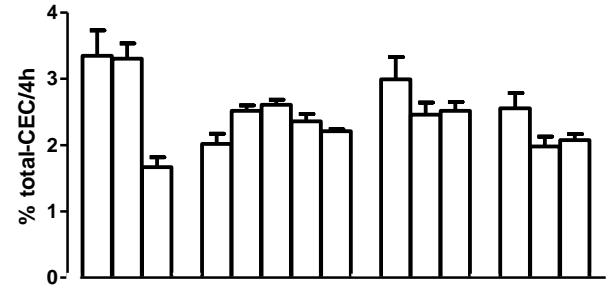

C)

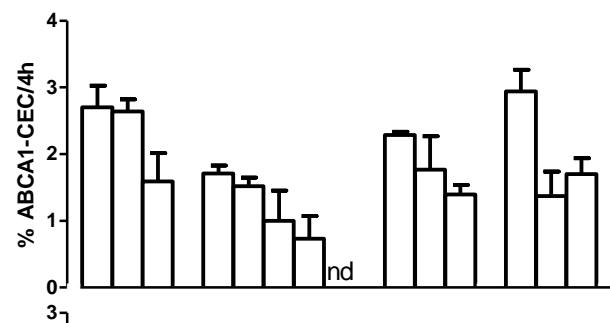

D)

E)

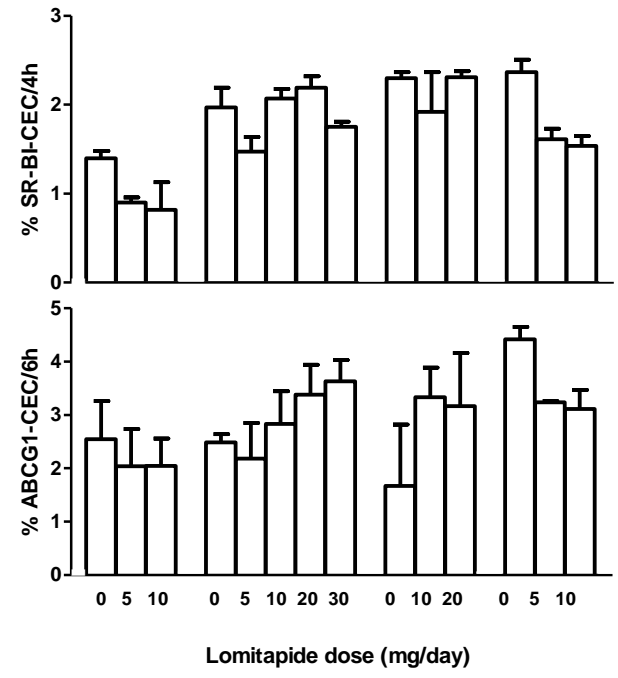

$\begin{array}{lllll}\text { Patients } & 1 & 2 & 3 & 4\end{array}$ 


\section{Discussion}

Our data confirm that lomitapide treatment decreases HDL-C levels. In depth analysis show a shift in $\mathrm{HDL}$ subclasses to larger buoyant $\mathrm{HDL}_{2}$. ABCA1-mediated cholesterol efflux decreased in all four HoFH patients, whereas changes in efflux via ABCG1, SR-BI and total cholesterol efflux were less consistent.

Previous studies showed that lomitapide treatment is associated with a moderate decrease of both HDL-C and ApoA-I levels during the titration period of the drug ${ }^{5-7}$. In line, we found a decrease in the levels of $\mathrm{HDL}-\mathrm{C}, \mathrm{ApoA}-\mathrm{I}$, pre $\beta-\mathrm{HDL}$, and $\mathrm{HDL}_{3}-\mathrm{C}$, which was most prominent on the lowest dose of lomitapide and remained stable thereafter. However, a shift of HDL to larger and more buoyant particles was observed with $\mathrm{HDL}_{2}-\mathrm{C}$ levels remaining unchanged or increased. A reduced formation of HDL during lipolysis of predominantly postprandial triglyceride rich lipoproteins (TGRL) may underlie the reduction in HDL and ApoA-I levels and the alterations in HDL subclass levels. Additionally, lomitapide may reduce the levels of HDL derived from the intestine, since MTP-deficiency has been reported to reduce HDL-cholesterol secretion from the intestine in mice ${ }^{19-21}$. In line with this shift in HDL subclasses, the ABCA1mediated cholesterol efflux was decreased in all patients, whereas changes in the ABCG1and SR-BI-mediated cholesterol efflux were less consistent.

As expected, lomitapide treatment decreased LDL-C and apoB levels substantially as well as the other atherogenic lipoproteins, i.e. IDL, VLDL, and $\operatorname{Lp}(a){ }^{5}$. Consistently, we found that lomitapide reduced the macrophage CLC of serum of all patients. This reflects the improved anti-atherosclerotic potential despite the moderate decrease of HDL-C ${ }^{22}$.

\section{Limitations}

The major limitation of this study is the small number of participants. Although two of the patients stopped lomitapide treatment this did not interfere with our analyses. 


\section{Conclusions}

Lomitapide treatment substantially lowered LDL-C levels, though it moderately reduced HDLC levels. However, $\mathrm{HDL}$ seemed to shift from $\mathrm{HDL}_{3}$ to the larger and more buoyant $\mathrm{HDL}_{2}$. In addition, the ABCA1-mediated cholesterol efflux decreased, whereas other pathways did not change consistently. Our report raises the hypothesis that the anti-atherogenic potential of HDL seems to be unaffected as total CEC did not seem to change consistently despite decreased HDL-C levels. Combined with the reduction of atherogenic lipoproteins, the net effect of lomitapide appears to be beneficial in HoFH patients. 


\section{Disclosures}

RY report a travel grant from Aegerion Pharmaceuticals, outside the submitted work. LC reports grants and personal fees from Medlmmune, and grants from The Medicines Company, and BioMarin Pharmaceutical, outside the submitted work. MA reports personal fees from Aegerion, Amgen, Chiesi, MSD, Mediolanum, Sanofi, Astra Zeneca, Mylan-Abbot, outside the submitted work. F. Bernini reports personal fees from Astra Zeneca, Milano, outside the submitted work. JRVL reports grants and fees from Sanofi and Aegerion, attributed to the institution, outside the submitted work. All other authors declare no conflicts of interest.

\section{Acknowledgments}

Aegerion Pharmaceuticals, for supplying the lomitapide for the patients

\section{Sources of Funding}

None. 


\section{References}

1. Abifadel M, Varret M, Rabes JP, Allard D, Ouguerram K, Devillers M, Cruaud C, Benjannet S, Wickham L, Erlich D, Derre A, Villeger L, Farnier M, Beucler I, Bruckert E, Chambaz J, Chanu B, Lecerf JM, Luc G, Moulin P, Weissenbach J, Prat A, Krempf M, Junien C, Seidah NG, Boileau C. Mutations in pcsk9 cause autosomal dominant hypercholesterolemia. Nat Genet. 2003;34:154156

2. Nordestgaard BG, Chapman MJ, Humphries SE, Ginsberg HN, Masana L, Descamps OS, Wiklund O, Hegele RA, Raal FJ, Defesche JC, Wiegman A, Santos RD, Watts GF, Parhofer KG, Hovingh GK, Kovanen PT, Boileau C, Averna M, Boren J, Bruckert E, Catapano AL, Kuivenhoven JA, Pajukanta P, Ray K, Stalenhoef AF, Stroes E, Taskinen MR, Tybjaerg-Hansen A, European Atherosclerosis Society Consensus P. Familial hypercholesterolaemia is underdiagnosed and undertreated in the general population: Guidance for clinicians to prevent coronary heart disease: Consensus statement of the european atherosclerosis society. Eur Heart J. 2013;34:3478-3490a

3. Raal FJ, Santos RD. Homozygous familial hypercholesterolemia: Current perspectives on diagnosis and treatment. Atherosclerosis. 2012;223:262-268

4. Cuchel M, Bruckert E, Ginsberg HN, Raal FJ, Santos RD, Hegele RA, Kuivenhoven JA, Nordestgaard BG, Descamps OS, Steinhagen-Thiessen E, Tybjaerg-Hansen A, Watts GF, Averna M, Boileau C, Boren J, Catapano AL, Defesche JC, Hovingh GK, Humphries SE, Kovanen PT, Masana L, Pajukanta P, Parhofer KG, Ray KK, Stalenhoef AF, Stroes E, Taskinen MR, Wiegman A, Wiklund O, Chapman MJ, European Atherosclerosis Society Consensus Panel on Familial $\mathrm{H}$. Homozygous familial hypercholesterolaemia: New insights and guidance for clinicians to improve detection and clinical management. A position paper from the consensus panel on familial hypercholesterolaemia of the european atherosclerosis society. Eur Heart J. 2014;35:2146-2157

5. Cuchel M, Meagher EA, du Toit Theron H, Blom DJ, Marais AD, Hegele RA, Averna MR, Sirtori CR, Shah PK, Gaudet D, Stefanutti C, Vigna GB, Du Plessis AM, Propert KJ, Sasiela WJ, Bloedon LT, Rader DJ, Phase 3 Ho FHLSi. Efficacy and safety of a microsomal triglyceride transfer protein inhibitor in patients with homozygous familial hypercholesterolaemia: A singlearm, open-label, phase 3 study. Lancet. 2013;381:40-46

6. Samaha FF, McKenney J, Bloedon LT, Sasiela WJ, Rader DJ. Inhibition of microsomal triglyceride transfer protein alone or with ezetimibe in patients with moderate hypercholesterolemia. Nat Clin Pract Cardiovasc Med. 2008;5:497505

7. Cuchel M, Bloedon LT, Szapary PO, Kolansky DM, Wolfe ML, Sarkis A, Millar JS, Ikewaki K, Siegelman ES, Gregg RE, Rader DJ. Inhibition of microsomal triglyceride transfer protein in familial hypercholesterolemia. $N$ Engl $J$ Med. 2007;356:148-156

8. Khera AV, Cuchel M, de la Llera-Moya M, Rodrigues A, Burke MF, Jafri K, French BC, Phillips JA, Mucksavage ML, Wilensky RL, Mohler ER, Rothblat $\mathrm{GH}$, Rader DJ. Cholesterol efflux capacity, high-density lipoprotein function, and atherosclerosis. N Engl J Med. 2011;364:127-135

9. Rohatgi A, Khera A, Berry JD, Givens EG, Ayers CR, Wedin KE, Neeland IJ, Yuhanna IS, Rader DR, de Lemos JA, Shaul PW. Hdl cholesterol efflux 
capacity and incident cardiovascular events. N Engl J Med. 2014;371:23832393

10. Roeters van Lennep J, Averna M, Alonso R. Treating homozygous familial hypercholesterolemia in a real-world setting: Experiences with lomitapide. Journal of clinical lipidology. 2015;9:607-617

11. Proudfoot JM, Barden AE, Loke WM, Croft KD, Puddey IB, Mori TA. Hdl is the major lipoprotein carrier of plasma f2-isoprostanes. J Lipid Res. 2009;50:716722

12. Kirstein P, Carlson K. Determination of the cholesterol content of high density lipoprotein subfractions hdl2 and hdl3, without contamination of Ip(a), in human plasma. Clin Chim Acta. 1981;113:123-134

13. Marcovina SM, Albers JJ, Scanu AM, Kennedy H, Giaculli F, Berg K, Couderc R, Dati F, Rifai N, Sakurabayashi I, Tate JR, Steinmetz A. Use of a reference material proposed by the international federation of clinical chemistry and laboratory medicine to evaluate analytical methods for the determination of plasma lipoprotein(a). Clin Chem. 2000;46:1956-1967

14. Favari E, Gomaraschi M, Zanotti I, Bernini F, Lee-Rueckert M, Kovanen PT, Sirtori CR, Franceschini G, Calabresi L. A unique protease-sensitive high density lipoprotein particle containing the apolipoprotein a-i(milano) dimer effectively promotes atp-binding cassette a1-mediated cell cholesterol efflux. $J$ Biol Chem. 2007;282:5125-5132

15. Adorni MP, Zimetti F, Puntoni M, Bigazzi F, Sbrana F, Minichilli F, Bernini F, Ronda N, Favari E, Sampietro T. Cellular cholesterol efflux and cholesterol loading capacity of serum: Effects of Idl-apheresis. J Lipid Res. 2012;53:984989

16. Vigna GB, Satta E, Bernini F, Boarini S, Bosi C, Giusto L, Pinotti E, Tarugi P, Vanini A, Volpato S, Zimetti F, Zuliani G, Favari E. Flow-mediated dilation, carotid wall thickness and hdl function in subjects with hyperalphalipoproteinemia. Nutr Metab Cardiovasc Dis. 2014;24:777-783

17. Favari E, Chroni A, Tietge UJ, Zanotti I, Escola-Gil JC, Bernini F. Cholesterol efflux and reverse cholesterol transport. Handb Exp Pharmacol. 2015;224:181-206

18. Nieland TJ, Shaw JT, Jaipuri FA, Duffner JL, Koehler AN, Banakos S, Zannis VI, Kirchhausen T, Krieger M. Identification of the molecular target of small molecule inhibitors of hdl receptor sr-bi activity. Biochemistry. 2008;47:460472

19. Tall AR, Blum CB, Forester GP, Nelson CA. Changes in the distribution and composition of plasma high density lipoproteins after ingestion of fat. J Biol Chem. 1982;257:198-207

20. Musliner TA, Long MD, Forte TM, Nichols AV, Gong EL, Blanche PJ, Krauss RM. Dissociation of high density lipoprotein precursors from apolipoprotein bcontaining lipoproteins in the presence of unesterified fatty acids and a source of apolipoprotein a-i. J Lipid Res. 1991;32:917-933

21. Iqbal J, Boutjdir M, Rudel LL, Hussain MM. Intestine-specific mtp and global acat2 deficiency lowers acute cholesterol absorption with chylomicrons and hdls. J Lipid Res. 2014;55:2261-2275

22. Weibel GL, Drazul-Schrader D, Shivers DK, Wade AN, Rothblat GH, Reilly MP, de la Llera-Moya M. Importance of evaluating cell cholesterol influx with efflux in determining the impact of human serum on cholesterol metabolism and atherosclerosis. Arterioscler Thromb Vasc Biol. 2014;34:17-25 
